\title{
Peripheral nerve blocks for the treatment of short-lasting unilateral neuralgiform headache with conjunctival injection and tearing (SUNCT) during pregnancy
}

\author{
Gebelikte konjunktival injeksiyon ve göz yaşarması ile birlikte kısa-süreli unilateral \\ nevraljifrm başağrısı ataklarında (SUNCT) periferal sinir blokajı tedavisi
}

\section{Osman Özgür YALIN,' Derya ULUDÜZ, ${ }^{2}$ Aynur ÖZGE}

\begin{abstract}
Summary
Short-lasting unilateral neuralgiform headache attacks with conjunctival injection and tearing (SUNCT) is a rare, primary headache syndrome, which is classified as a subtype of trigeminal autonomic cephalalgias. Although SUNCT is usually refractory to treatment, several antiepileptic drugs have recently shown promising results for its treatment. However, there is a lack of evidence regarding the course of SUNCT during pregnancy and the available treatment options. Here, we present a 30-week pregnant female with SUNCT who was successfully treated with infra- and supraorbital nerve blocks. Headache attacks completely diminished after the injection, and recurrence was not observed. Although lamotrigine may be relatively safe in pregnant patients with SUNCT attacks, peripheral nerve block may be a feasible technique and can be considered as a safe and effective treatment option. This is the first SUNCT case in the literature that was successfully treated with infra- and supraorbital nerve blocks during pregnancy.
\end{abstract}

Keywords: Infraorbital; nerve block; SUNCT; supraorbital.

\begin{abstract}
Özet
Konjunktival injeksiyon ve göz yaşarması ile birlikte kısa-süreli unilateral nevraljifrm başağrısı atakları (SUNCT), trigeminal otonomik başağrıları içerisinde sınıflandırılan nadir gözlenen bir primer başağrısı bozukluğudur. SUNCT genellikle tedaviye dirençli bir sendrom olarak kabul edilmesine rağmen son yıllarda antiepileptik ilaçlar ile anlamlı düzelme bildirilmektedir. Hastalığın gebelikteki seyri ve tedavisi ile ilgili literatürde bilgi yoktur. Bu çalışmada 30 haftalık gebelik sırasında SUNCT atağı yaşayan, infra- ve supraorbital sinir blokajı ile başarılı bir şekilde tedavi edilen bir olgu sunulmaktadır. Aslında gebelik döneminde lamotrijin kısmen güvenli olarak kullanılmaktadır, fakat periferal sinir blokajı uygulanması pratik, güvenli ve etkin bir alternatif tedavi seçeneğidir. Bu olgu literatürde gebelik döneminde infra- ve supraorbital sinir blokajı ile başarılı bir şekilde tedavi edilen ilk SUNCT hastasıdır.
\end{abstract}

Anahtar sözcükler: Infraorbital; sinir blokajı; SUNCT; supraorbital.

\section{Introduction}

Trigeminal autonomic cephalgia (TAC) is usually defined as the occurrence of unilateral, brief, severe, and high-frequency headache attacks accompanied with ipsilateral parasympathetic autonomic features. According to the International Classification of Headache Disorders, 3rd Edition (ICHD-3), ${ }^{[1]}$ short-lasting unilateral neuralgiform headache attacks (SUNCT and SUNA) are characterized by shortest attacks of TAC (15-600 s). The diagnosis of SUNCT is based on the presence of conjunctival injection and tearing, although there is an ongoing debate whether they are subtypes of the same disorder. SUNCT is also classified as chronic or episodic based on the frequency of attacks (months or years). ${ }^{[1]}$

We report the case of a woman with SUNCT whose attacks remitted during the third trimester of a healthy pregnancy. There are no guidelines for the

\footnotetext{
'Department of Neurology, Training and Research Hospital, Istanbul, Turkey

${ }^{2}$ Department of Neurology, Istanbul University Cerrahpasa Faculty of Medicine, Istanbul, Turkey

${ }^{3}$ Department of Neurology, Mersin University Faculty of Medicine, Mersin, Turkey

Correspondence: Dr. Osman Özgür Yalın. İstanbul Eğitim ve Araştırma Hastanesi, Nöroloji Kliniği, İstanbul, Turkey.

Phone: +90 - 212 - 4596230 e-mail: osmanozguryalin@yahoo.com

(c) 2018 Turkish Society of Algology
}

Submitted (Başvuru tarihi) 04.02.2016 Accepted after revision (Düzeltme sonrası kabul tarihi) 29.09.2016 Available online date (Online yayımlanma tarihi) 29.01.2018 
management of such a case, and management strategy becomes more complex due to potential teratogenicity during pregnancy. The course of this uncommon condition during pregnancy has been poorly explored, and to the best of our knowledge, there are no reports that evaluated the therapeutic strategies for treating SUNCT in pregnant females.

\section{Case Report}

A 29-year-old female who was 30 weeks pregnant presented with a 13-year history of recurrent and seasonal (usually in autumn) headache attacks. She described strictly unilateral (always left-sided), stabbing, episodic pain in the periorbital area that lasted for a few seconds to $2 \mathrm{~min}$, accompanied with prominent facial flushing, conjunctival injection, lacrimation, and rhinorrhea. The pain usually occurred $>10$ times daily for 15 days to 1 month, clustering once a year. Previous attacks which were diagnosed as sinusitis were treated with antibacterial agents, and they usually lasted for a month without treatment. However, the current SUNCT attack lasted for 1 week. The headache attacks were triggered by touching and washing face, without a refractory period. When the patient presented to us, she was 30 weeks pregnant and healthy. This was her first pregnancy and without complications or high blood pressure; obstetric ultrasound and other examination results were normal. Neurological examination result was normal, except mild allodynia in the left periorbital area and attacks with prominent tearing and conjunctival injections triggered due to touching. She was diagnosed with SUNCT according to the ICHD-3 beta criteria. Magnetic resonance imaging (MRI) performed 1 year prior had revealed normal findings. After the final diagnosis, clinicians explained the medical treatment options to the patient and her relatives; however, the patient did not approve of using any drugs because of pregnancy and wanting to breastfeed. Then, we discussed infra- and supraorbital nerve block treatment and obtained written informed consents from the patient and obstetricians. The supra- and infraorbital nerve block was performed with the patient in the supine position and head maintained in a neutral position. A 22-25-gauge and 1.5-inch needle was advanced through the foramen, and $4 \mathrm{ml}$ of lidocaine (10 mg)+bupivacaine (5 mg)+metilprednisolone (40 $\mathrm{mg}$ ) for each nerve was injected without any complication. Follow-up visits were conducted at 1 week, 1 month, and 3 months after the procedure. Pain attacks completely diminished after the first injection, and recurrence was not observed until 1 year. The patient delivered a healthy baby girl, and the delivery was uneventful. Furthermore, the baby has been breastfed to date. The patient's written consent has been obtained for the publication of this case study.

\section{Discussion}

The treatment for SUNCT is traditionally regarded as challenging. ${ }^{[2,3]}$ Although exact pathophysiology of SUNCT remains unclear, recent studies have revealed signs of activation at the nucleus caudalis and posterior hypothalamus. The activation of the peripheral trigeminovascular complex is induced by the activation of the central pain pathways, including the posterior hypothalamus. Recent studies have reported satisfactory results using antiepileptic drugs; currently, the first-line agent is lamotrigine, whereas the second-line drugs include gabapentin and topiramate. ${ }^{[4,5]}$ For severe and treatment-resistant patients, there are pioneer studies on deep brain stimulation and microvascular surgery. ${ }^{[6-9]}$ Some authors have reported conflicting results regarding the efficacy of great occipital nerve (GON) block. Supra- and infraorbital nerve blocks for treating SUNCT have been rarely studied. Some studies have reported improvements in patients treated with GON injections. ${ }^{[9,}{ }^{10]}$ Cohen et al. ${ }^{[11]}$ reported satisfactory results for the use of GON block in treating patients with SUNCT. In a series of patients, Pareja et al. ${ }^{[3]}$ reported that GON and supra- and infraorbital blocks were not beneficial in patients with SUNCT. McLauhchlan et al. ${ }^{[12]}$ reported a SUNCT case which was effectively treated with supra- and infraorbital nerve blocks.These contradictory results could be due to differences in the blocking agents and dosage of the blocking technique. Because SUNCT is a rare disorder, there are no controlled trials that investigated the efficacy of medical treatments and invasive procedures for its treatment. We have not come across any case of SUNCT during pregnancy in the literature. To the best of our knowledge, our study is the first to report the case of a pregnant female who was successfully treated with infra- and supraorbital nerve blocks along with steroids bupivacaine and lidocaine. Although lamortigine administration seems relatively safe during pregnancy, its safety during breastfeeding has not been well studied; therefore, 
alternatively, nerve block may be regarded as a safe, easy-to-perform treatment option for SUNCT.

\section{Conflict-of-interest issues regarding the author- ship or article: None declared.}

\section{Peer-rewiew: Externally peer-reviewed.}

\section{References}

1. Headache Classification Committee of the International Headache Society (IHS). The International Classification of Headache Disorders, 3rd edition (beta version). Cephalalgia 2013;33(9):629-808.

2. Cohen AS, Matharu MS, Goadsby PJ. Short-lasting unilateral neuralgiform headache attacks with conjunctival injection and tearing (SUNCT) or cranial autonomic features (SUNA)-a prospective clinical study of SUNCT and SUNA. Brain 2006;129(Pt 10):2746-60. [CrossRef]

3. Pareja JA, Caminero AB, Sjaastad O. SUNCT Syndrome: diagnosis and treatment. CNS Drugs 2002;16:373-83. [CrossRef]

4. Lambru G, Matharu MS. SUNCT and SUNA: medical and surgical treatments. Neurol Sci 2013 May;34 Suppl 1:S75-81.

5. Pomeroy JL, Nahas SJ. SUNCT/SUNA: A Review. Curr Pain Headache Rep 2015;19(8):38. [CrossRef]

6. Lyons MK, Dodick DW, Evidente VG. Responsiveness of short-lasting unilateral neuralgiform headache with conjunctival injection and tearing to hypothalamic deep brain stimulation. J Neurosurg 2009;110(2):279-81. [CrossRef]

7. Bartsch T, Falk D, Knudsen K, Reese R, Raethjen J, Mehdorn $\mathrm{HM}$, et al. Deep brain stimulation of the posterior hypothalamic area in intractable short-lasting unilateral neuralgiform headache with conjunctival injection and tearing (SUNCT). Cephalalgia 2011;31(13):1405-8. [CrossRef]

8. Irimia P, González-Redondo R, Domínguez PD, Díez-Valle $R$, Martínez-Vila E. Microvascular decompression may be effective for refractory SUNCT regardless of symptom duration. Cephalalgia 2010;30(5):626-30. [CrossRef]

9. Choi HJ, Choi SK, Lee SH, Lim YJ. Whiplash injury-induced atypical short-lasting unilateral neuralgiform headache with conjunctival injection and tearing syndrome treated by greater occipital nerve block. Clin J Pain 2012;28(4):342-3.

10. Porta-Etessam J, Cuadrado ML, Galán L, Sampedro A, Valencia $C$. Temporal response to bupivacaine bilateral great occipital block in a patient with SUNCT syndrome. J Headache Pain 2010;11(2):179. [CrossRef]

11. Cohen AS, Matharu MS, Goadsby PJ. Trigeminal autonomic cephalalgias: current and future treatments. Headache 2007;47(6):969-80. [CrossRef]

12. McLauchlan D, Robertson M, Drage NP. Sunct: A novel therapeutic approach. J Neurol Neurosurg Psychiatry 2012;83(2):6. [CrossRef] 